\title{
Land Use Planning for Post-Disaster Soil Liquefaction Area Based on Erosion Hazard Index
}

\author{
Naharuddin Naharuddin*, Adam Malik, Imran Rachman, Hasriani Muis, Hamzari Hamzari, Abdul Wahid \\ Department of Forestry, Faculty of Forestry, Tadulako University, Palu 94119, Central Sulawesi, Indonesia
}

Corresponding Author Email: naharuddin.sumani@untad.ac.id

https://doi.org/10.18280/ijdne.150415

Received: 28 May 2020

Accepted: 30 July 2020

\section{Keywords:}

Watershed, erosion hazard, land use, GIS, USLE, tsunami

\begin{abstract}
The erosion is a very complex problem that can damage environmental ecosystems and land productivity. The main objective of this study is to predict soil erosion in Watutela watershed after the earthquake using GIS combination with the USLE method. The results showed that the erosion hazard index in the Watutela watershed was between the low to high criteria. The danger of high erosion was found in empty land about 427.93 tons/ha/year. While on the other hand, low criteria occurred in the shrubs 26.07 tons/ha/year. The results obtained allow determining as the Palu City development zone and to minimize the erosion hazard index, soil, and water conservation needs to be done through reforestation, rehabilitation utilization of tree architecture models that function in controlling erosion and climate, especially in high erosion hazard class.
\end{abstract}

\section{INTRODUCTION}

The occurrence of soil erosion is recognized globally as a serious problem $[1,2]$. Southeast Asia is among the regions facing the most severe impact of climate change [3, 4]. Soil erosion, one of the most severe problems in the 21 st century $[5,6]$. Around 70 billion tons/year of land erosion in the world comes mostly from agricultural land.

Land productivity in a watershed gradually decreases by \pm 20 million ha/year. Highly exploitative land use does not only ecologically harm the environment but also the economy, and must be surmounted [7]. Not only inhibits sustainable land management, but soil erosion also causes other people's live problems [8, 9].

Land degradation is caused by erosion and conversion of forest to other land uses that ignore the principles of land and water conservation $[10,11]$. The quality of a watershed depends on land management and suitability as well as its carrying capacity [12].

Prediction of erosion hazard index is important for current or future land use planning [13]. It is known that erosion produces sediment. The model of Universal Soil Loss Equation (USLE) that is based on geographic information system has been widely used to estimate the amount of sediment in many watersheds throughout the world both nationally and regionally $[2,14]$. In Indonesia itself, USLE has been developed as a model to compare erosion that occurs in forests, rice fields, plantations, and residential areas $[15,16]$.

A method with Geographic Information Systems (GIS) approach combined with the USLE model as a means of erosion hazard index prediction has weaknesses such as the model is seen to be ineffective if applied outside the condition of where the model was developed. The adaptation of this model to a new environment requires an investment of resources and time to develop the database needed [17]. Despite USLE method has a drawback, but the methods are still widely used in various studies erosion prediction. Mentioned that erosion prediction with the USLE model is very important to map out the areas they need specific management [18].

USLE is a simple and reliable analysis in the land management perspective on an ongoing basis [19]. Erosion prediction with the USLE model is essential as a basis to determine the hazard and risk of erosion $[18,20]$. Besides that, the valuation of soil sensitivity to erosion is significant in the effort of land conservation and management [21, 22]. Assessment of soil erosion using USLE and GIS is the basis for making land use judgment soil and ecosystem conservation [23].

The study on soil erosion and hazard index uses the USLE combination of GIS model been done [24-26] the data produced has the excellence and the latest information, it is significant to concatenate [27].

The research to map the erosion hazard index urgent in Watutela watershed. Based on these data, the erosion hazard index in the framework of land use planning can be used as a guideline in the framework of conservation strategies for the restoration and rehabilitation of watershed ecosystems both inside and outside the forest area.

The erosion hazard index is a comparison between the amount of erosion that occurs that will endanger the sustainability of soil productivity. To maintain soil productivity, land management should be adjusted to the principles of soil conservation.

Watutela watershed is located in the eastern region of Palu City, Central Sulawesi. The ID Number is 183419 and have over 923.01 ha catchment areas. It has a quite large height differencing to cause flooding debris which carries a big amount of sedimentation. The area is prone to soil and cliff erosion. The existence of this watershed has an important role in the lives of the people in the eastern region of Palu City. Not only as a regional system of water supply in Palu, but Watutela watershed is also classified as a yellow zone/development area (a zone that is prone to liquefaction, tsunamis, soil movement, flood).

Although this region is already declared as a development 
area based on the disaster-prone zone map of Palu City, the data of environmental baseline especially the data of erosion hazard index is not yet available as a basis for policymaking. Therefore, it is necessary to study the prediction of erosion hazard index and the effect of land use on the rate of erosion. It is believed that the results can be used as a foundation for watershed planning in an environmentally sustainable manner and for the strategy of vegetative and mechanical conservation. Based on this matter, the goal of this study is to predict soil erosion in Watutela watershed after the earthquake using GIS combination with the USLE method.

\section{STUDY AREA AND DATA}

This research location is in Watutela watershed, Palu City, Central Sulawesi, with coordinates between longitudes 119'52'46.58"E and 119'56'1.31"E, and latitudes 0'49'12.64"S and $0^{\prime} 50^{\prime} 32,8$ 'S. Based on natural conditions, the Watutela watershed is surrounded by Palu Bay and Mount Verbecs. The map of Watutela watershed is presented in Figure 1.

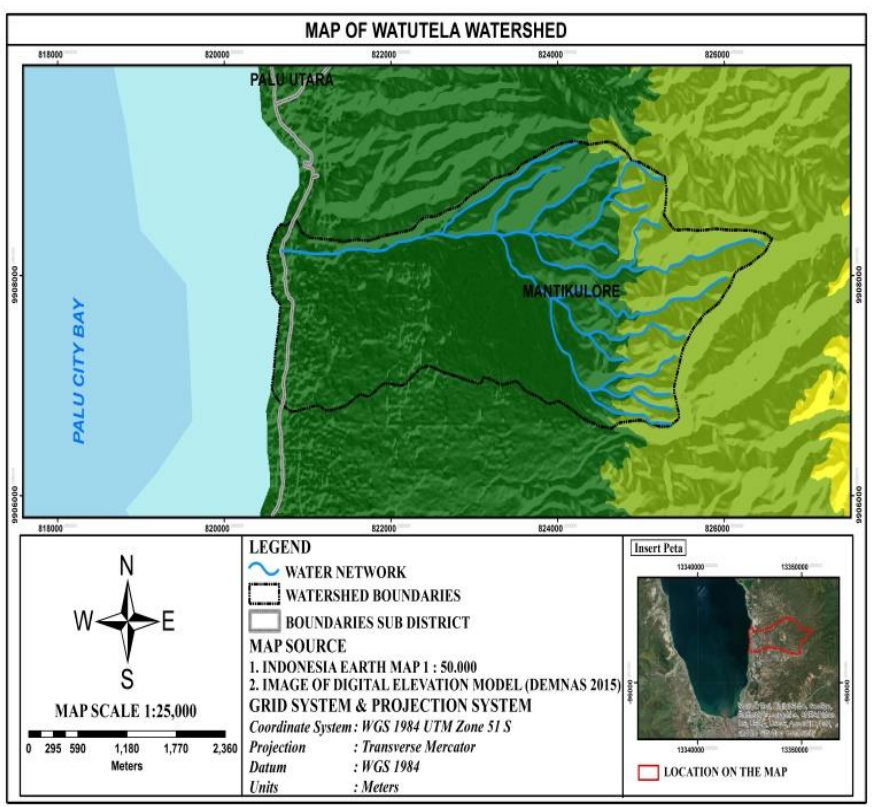

Figure 1. Research Location, Watutela Watershed

The data for an index of erosion hazard analysis in this study were: (1) the data of rainfall in the last 5 years starting from 2014 to 2018, (2) the Landsat imagery 8 bands 654, (3) the map of Watutela watershed, (4) administration map, (5) the slope map, (6) the soil type map, (7) the land use map, (8) the map of Indonesia on scale 1:25,000, and (9) data actual erodibility of each unit, and type of land use, and land conservation.

\section{METHODOLOGY}

The combination of the application of GIS and USLE methods is carried out through the process of collecting primary and secondary data. Primary data obtained from a ground check, observation on the actual erodibility of each unit, and type of land use, as well as land conservation. The observation was performed based on the results of the Landsat 8 band 654 imagery interpretation. Whereas, the secondary data consisted of (1) spatial data. It is in the form of a digital map from watershed and Forest Management Center of PaluPoso containing slope grade, soil type, rainfall distribution pattern, and land use pattern; (2) non-spatial data that is in the form of rainfall data from Meteorological Station of Mutiara Palu and sub-district data from the Central Sulawesi of Statistics of Mantikulore Sub-district, Palu City; (3) other supporting data such as results from previous research and scientific publications as well as results from spatial planning of Palu City post-earthquake, tsunami, and soil liquefaction

The data analysis of this study was implemented using GIS with a projection system and Universal Transverse Mercator (UTM) as the coordinates. The unit in this measurement is a meter so that the analysis that required distance and area information can be arranged utilizing overlaying the maps. Then, the data were calculated using the USLE formula [2229]:

$$
\mathrm{A}=\mathrm{R} \times \mathrm{K} \times \operatorname{LS} \times \mathrm{C} \times \mathrm{P}
$$

where, A: the amount of soil loss due to erosion (ton/ha/year), $\mathrm{R}$ : rainfall erosivity index, K: soil erodibility factor, LS: land length and slope factor, $\mathrm{C}$ : vegetation and plant management factor, P: land management/soil conservation factor.

In determining the erosion hazard index, the researchers used this following Equation 2 that is adapted from [30, 31]:

$$
\mathrm{EHI}=\mathrm{A} / \text { Etol }
$$

where, EHI: erosion hazard index (ton/ha/year), A: soil erosion rate (ton/ha/year), Etol: soil erosion that can be tolerated (mm/year).

Etol values are calculated based on the data in Table 1.

Furthermore, Table 2 is used to determine the classification of the index erosion. Data refers to the study $[22,32]$ :

Table 1. Guidelines for determining Etol value for soils in

\begin{tabular}{|c|c|}
\hline Soil and substratum properties & $\begin{array}{l}\text { Etol value } \\
\text { (mm/year) }\end{array}$ \\
\hline Very shallow soil above rocks & 0.0 \\
\hline $\begin{array}{l}\text { Very shallow soil above moldy materials } \\
\text { (not consolidated) }\end{array}$ & 0.4 \\
\hline Shallow soil above moldy materials & 0.8 \\
\hline Moderate depth soil above moldy materials & 1.2 \\
\hline $\begin{array}{l}\text { Deep soil with the impermeable lower layer } \\
\text { above moldy materials }\end{array}$ & 1.4 \\
\hline $\begin{array}{c}\text { Deep soil with slow permeability lower layer } \\
\text { above moldy materials }\end{array}$ & 1.6 \\
\hline $\begin{array}{l}\text { Deep soils with medium permeability lower } \\
\text { layer above moldy materials }\end{array}$ & 2.0 \\
\hline $\begin{array}{l}\text { Deep soils with fast permeability lower layer } \\
\text { above moldy materials }\end{array}$ & 2.5 \\
\hline
\end{tabular}
Indonesia [33]

Table 2. Erosion hazard index classification

\begin{tabular}{ccc}
\hline $\begin{array}{c}\text { Erosion rate } \\
\text { (ton/ha/year) }\end{array}$ & $\begin{array}{c}\text { Erosion hazard index } \\
\text { classification }\end{array}$ & Description \\
\hline$<15$ & I & Very Low \\
$15-60$ & II & Low \\
$60-180$ & III & Medium \\
$180-480$ & IV & High \\
$>480$ & V & Very High \\
\hline
\end{tabular}




\section{RESULTS AND DISCUSSIONS}

\subsection{Land use}

The results analysis of the GIS method and ground check and the interpretation of Landsat 8 band 654 images, Watutela watershed has four types of land use namely shrubs, dryland farming, empty land, and settlement (Table 3 and Figure 2).

Table 3. Watutela Watershed land use

\begin{tabular}{ccc}
\hline Land use/codes & \multicolumn{2}{c}{ Area } \\
\cline { 2 - 3 } & Ha & \% \\
\hline Shrubs (SB1) & 115.86 & 12.55 \\
Empty Land (EL) & 2.32 & 0.25 \\
Shrubs (SB2) & 94.56 & 10.25 \\
Settlements (SM) & 420.43 & 45.55 \\
Shrubs (SB3) & 35.42 & 3.84 \\
Shrubs (SB4) & 249.34 & 27.01 \\
Dryland Farming (DF) & 5.07 & 0.55 \\
\hline Total & 923.01 & 100.00
\end{tabular}

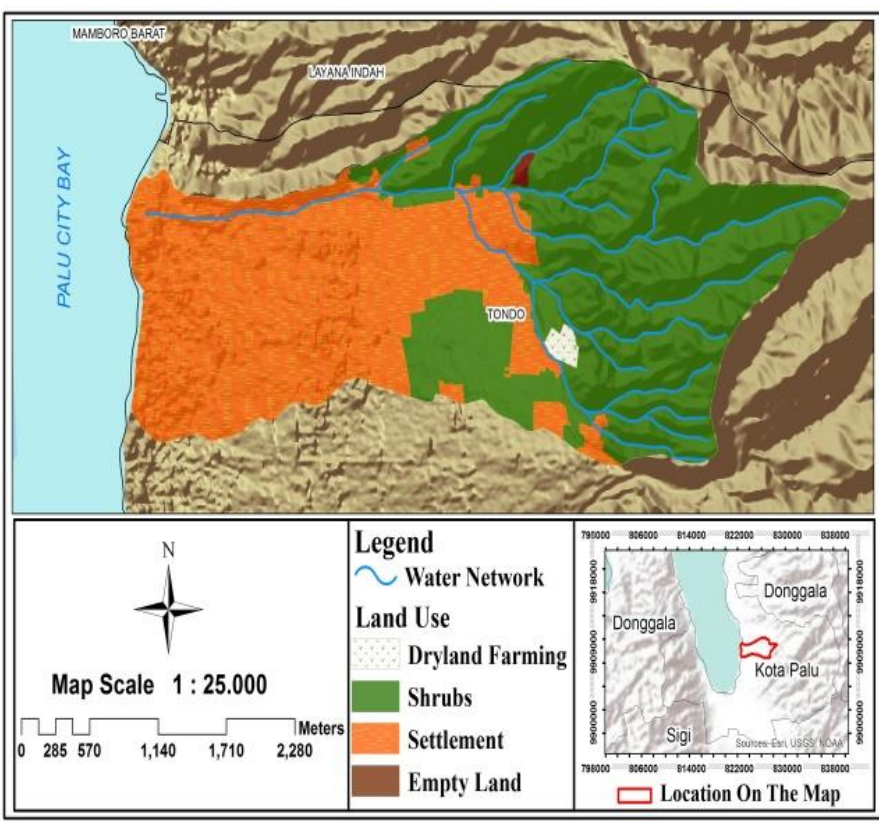

Figure 2. Land use map of Watutela Watershed

Watutela Watershed is dominated by shrubs amounting to 495.19 ha $(53.65 \%)$ (Table 3 and Figure 2) it shows that the land forest vegetation has degradation, this will lead to surface runoff and erosion. The use of forest areas affects the rate of surface runoff and erosion. If the forest area decreases, it will not only cause increased soil erosion but will also cause a reduction in water catchment areas, resulting in a decrease in water storage capacity that can increase erosion [16].

In this study, the settlement area is 420.43 ha and is not identified as the unit of analysis because settlement or residential area is not prioritized for soil and water conservation plan.

\subsection{Rainfall erosivity index}

Rainfall erosivity is the deciding factor in erosion rate. The intensity, thickness, and duration of the rain will largely determine the erosion. In a hydrological system, rain is one form of input into the watershed and can change from time to time which depends on climate change. Rainfall erosivity is the most dynamic factor that affects the variability of soil erosion rate [34]. Therefore, the average erosivity $(\mathrm{R})$ value in the last 5 years (2014-2018) is 462 (Table 4).

Table 4. Rainfall erosivity index $(\mathrm{R})$

\begin{tabular}{ccc}
\hline Month & Rainfall (cm th-1) & R $(\mathbf{m m})$ \\
\hline January & 6.93 & 39.5595 \\
February & 6.19 & 36.4885 \\
March & 8.14 & 44.581 \\
April & 6.9 & 39.435 \\
May & 6.65 & 38.3975 \\
June & 12.78 & 63.837 \\
July & 8.49 & 46.0335 \\
August & 0.4 & 12.46 \\
September & 6.38 & 37.2936 \\
October & 6.59 & 38.1485 \\
November & 4.89 & 30.8611 \\
December & 5.72 & 34.538 \\
\hline \multicolumn{3}{c}{ Total } \\
\hline
\end{tabular}

From the calculation of rainfall erosivity index $(\mathrm{R})$ using the average by the month rainfall data in the Table 4 , Watutela watershed has a Rainfall erosivity value of $462 \mathrm{~mm}$. The erosivity value indicator indicates a high occurrence of surface runoff on Watutela watershed. This runoff carries soil particles from the damage to soil aggregates due to strong rain pressure (kinetic energy of the rainfall). If the rain volume and intensity is high, the potential for surface runoff and erosion is also high. Erosivity is affected by the rainfall directly to the ground and partly due to the flow of water the land through the surface runoff process. Direct raindrops can erode the land surface slowly, and the accumulation of rainfall intensity will eventually cause erosion. This is in line with the statement [35], the rainfall causes the greetest proportion of runoff and soil loss.

\subsection{Soil erodibility value}

Soil erodibility is the sensitivity of soil to erosion. Each soil type has a different sensitivity. The results showed that the soil erodibility of each land unit in this study has a low to high classification.

Table 5, shows there are differences in the value of soil erodibility on each land unit. This happens due to the nature of the soil such as texture, permeability, structure, and organic contents where the permeability value and organic contents can change at any time along with the changes in land use. The soil properties influence each other which then will determine the level of soil erodibility.

Table 5. Erodibility value (K)

\begin{tabular}{ccc}
\hline Land use/codes & Erodibility (K) & Classification \\
\hline Shrubs (SB1) & 0.23 & Medium \\
Empty Land (EL) & 0.38 & Slightly High \\
Shrubs (SB2) & 0.24 & Medium \\
Shrubs (SB3) & 0.18 & Low \\
Shrubs (SB4) & 0.17 & Low \\
Dryland Farming (DF) & 0.19 & Medium \\
\hline
\end{tabular}

The sensitivity of soil erodibility is a function of various interactions of soil physical and chemical properties and other environmental factors. The greeter the soil erodibility value, the higher the erosion. Empty land has a high level of erodibility compared to other land uses such as forests. This is confirmed by the results of research $[2,36]$ that soil erosion is 
influenced by changes in land use conversion.

High land-use intensity causes a decrease in soil aggregate stability and permeability. The results of research on the physical and chemical characteristics of the soil, the texture of dusty soil in empty land is equal to $57.5 \%$. This number is higher compared to other fractions. It is found that the contents of organic material in the empty land is very low et $5.79 \%$. Empty land is susceptible to erosion due to dusty soil content, which has a finer size than other fractions so that it is easily carried by water during heavy rainfall. Aside from its size, dust cannot form bonds and as a result, this fraction is easily destroyed by rainwater and causes erosion. Organic contents influence the ability of the soil to minimize the rate of erosion.

\subsection{Land length and slope factor}

The results showed that the LS value on each land unit has a slightly steep-sloping classification (Table 6).

Table 6. Land length and slope value (LS)

\begin{tabular}{ccccc}
\hline Land use/codes & L & S & LS & Classification \\
\hline Shrubs (SB1) & 1.305 & 0.10 & 4.39 & Slightly Steep \\
Empty Land (EL) & 264 & 0.07 & 1.95 & Sloping \\
Shrubs (SB2) & 1.396 & 0.06 & 4.48 & Slightly Steep \\
Shrubs (SB3) & 1.031 & 0.09 & 2.09 & Sloping \\
Shrubs (SB4) & 1.486 & 0.13 & 3.94 & Slightly Steep \\
Dryland Farming (DF) & 300 & 0.07 & 4.63 & Slightly Steep \\
\hline
\end{tabular}

Table 6, explains that shrubs, in general, have a slightly steep classification (SB1, SB2, and SB4) compared to empty land which has a sloping classification. This means that an area with a slightly steep classification has higher runoff carrying more soil particles. The higher the slope, the higher the number of soil particles carried to the bottom because of raindrops. If the degree of the steep is 2 times higher, then the amount of erosion on each land unit becomes 2.0 to 2.5 times bigger [33]. According to Kinnell [37], the effect of slope length on soil loss per unit area is often considered to vary with slope length to a power greater than zero and less than 1 .

\subsection{Plant management and conservation measures}

The index of plant management and conservation measures (CP) is obtained from land-use data and conservation actions performed on each land unit. The results of the analysis are adjusted to the grouping of CP factor values (Table 7).

Table 7, above points out that the highest $\mathrm{CP}$ value occurs in the use of empty land. On the one hand, the $\mathrm{CP}$ value of shrubs on average is 0.3 while dryland farming is 0.2 . Thus, it can be concluded that vegetation affects the rate of erosion in protecting the soil surface from the damage of raindrops. vegetation has a significant impact on the formation and transportation of sediments in the form of soil erosion [38]. Believed that each type of plant has a different ability to hold erosion rates. This occurs because the effectiveness of plants in reducing erosion rates is influenced by several factors including: plant height and canopy continuity, organic matter, plant root systems, and plant density. Litter production also contributes to controlling runoff and erosion.

Table 7. Factors of plant management and conservation measures (CP)

\begin{tabular}{cccc}
\hline Land use/codes & C & P & CP \\
\hline Shrubs (SB1) & 0.3 & 1 & 0.3 \\
Empty Land (EL) & 1 & 1 & 1 \\
Shrubs (SB2) & 0.3 & 1 & 0.3 \\
Shrubs (SB3) & 0.3 & 1 & 0.3 \\
Shrubs (SB4) & 0.3 & 1 & 0.3 \\
Dryland Farming (DF) & 0.5 & 0.4 & 0.2 \\
\hline
\end{tabular}

\subsection{Erosion hazard index classification}

Based on the results of overlaid maps and calculation from GIS as well as field observation and USLE, it is known that the biggest erosion occurs on shrubs and empty land with a sloping and slightly steep classification (Table 8).

Table 8 , it can be seen that 2.32 ha of empty land (EL) has an erosion hazard index with a total erosion of 342.23 ton/ha/year. This is classified as a high rate of erosion because the tolerable erosion rate is $0.8 \mathrm{~mm} /$ year. The same thing also happened in 94.56 ha of shrubs (SB2) with a total erosion of 149.02 tons/ha/year. The erosion rate that can be tolerated in this area is $0.4 \mathrm{~mm} / \mathrm{year}$. The erosion hazard index for other shrublands SB1, SB3, and SB4 is in the low to medium classification. This is due to the differences in the value of erosion that can be tolerated. Nevertheless, dryland farming has a medium erosion hazard index classification. The high classification of erosion hazard index on empty land (EL) and shrubs (SB2) happened because it has a high level of soil density with very slow permeability compared to other land uses $4.54 \mathrm{~cm} /$ hour for empty land (EL) and $2.86 \mathrm{~cm} /$ hour for shrubs (SB2)). Very slow permeability leads to higher surface runoff and erosion rates. The condition is influenced by the texture of the dominant soil with dust. Low, medium, and high erosion (Figure 3).

Land in Watutela watershed mainly in the appropriate empty land (Figure 3) has been encroached causing a high level of erosion hazard. Land cover affects erosion [11]. Land conditions are subject to high disturbance for some time: especially overgrazing, and climate change with high rainfall intensity can increase erosion and decrease land quality [39]. Changes in land use can affect the risk of natural disasters [40].

The Watutela watershed is dominant with the land cover shrubs. Besides reforestation, it is also necessary to plant small-leaf crops and deep root systems to prevent the kinetic energy of raindrops, especially on an empty land with high erosion rates.

Table 8. Erosion hazard index classification

\begin{tabular}{ccccc}
\hline Land use/codes & A (ton/ha/year) & Etol (mm/year) & EHI (ton/ha/year) & Description \\
\hline Shrubs (SB1) & 139.94 & 1.4 & 99.96 & Medium \\
Empty Land (EL) & 342.34 & 0.8 & 427.93 & High \\
Shrubs (SB2) & 149.02 & 0.4 & 372.55 & High \\
Shrubs (SB3) & 52.14 & 2.0 & 26.07 & Low \\
Shrubs (SB4) & 92.83 & 1.4 & 66.31 & Medium \\
Dryland Farming (DF) & 81.28 & 1.2 & 67.74 & Medium \\
\hline
\end{tabular}




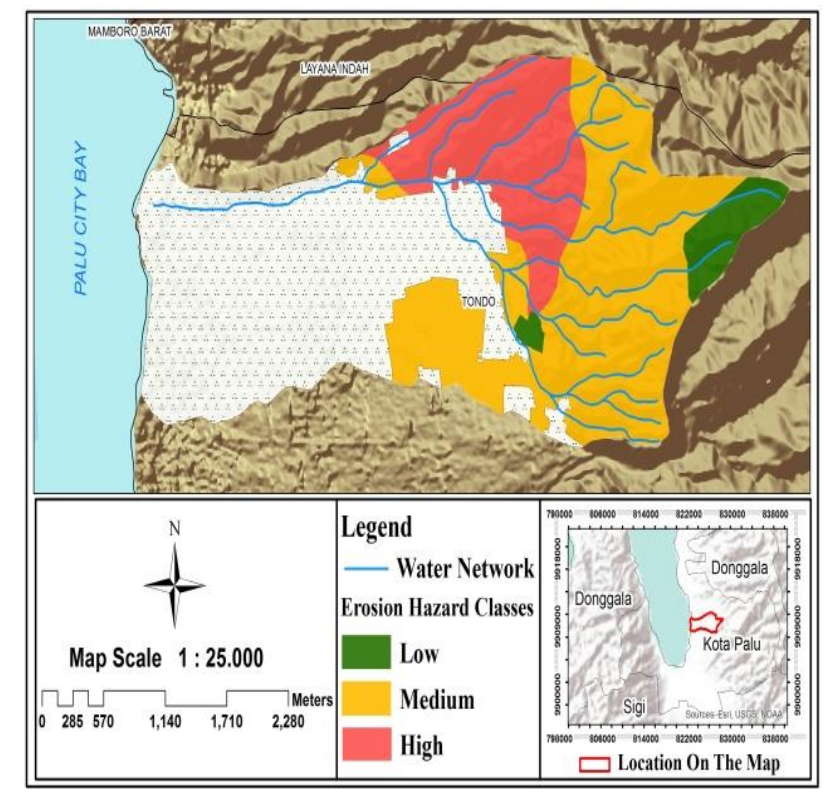

Figure 3. Map of erosion hazard classification

\section{CONCLUSIONS}

An empty land has the highest erosion rate amounting to 342.23 tons/ha/year. Meanwhile, the lowest erosion rate occurs in shrubs land (SB3) with a value of 52.14 tons/ha/year. The high erosion hazard index is found in empty land (EL) of 427.93 tons/ha/year and shrubs (SB2) of 372.55 tons/ha/year. Meanwhile, a low hazard index occurs in other shrubs (SB3) of 26.07 tons/ha/year.

Considering that the area of Watutela watershed is designated as the development area of Palu City, after the earthquake, tsunami, and land liquefaction in 2018, it needs a community development and reforestation strategy that is integrated with sustainable and environmentally-friendly forest, soil, and water rehabilitation programs, so that, the plants can function as controllers of water and climate.

\section{ACKNOWLEDGMENT}

The authors thank the Dean of the Faculty of Forestry, Tadulako University, who provided facilities with assignment letter No. 2257/U28.1.29/KP/2019.

\section{REFERENCES}

[1] Geißler, C., Lang, A.C., von Oheimb, G., Härdtle, W., Baruffol, M., Scholten, T. (2012). Impact of tree saplings on the kinetic energy of rainfall-The importance of stand density, species identity and tree architecture in subtropical forests in China. Agricultural and Forest Meteorology, 156: 31-40. https://doi.org/10.1016/j.agrformet.2011.12.005

[2] Wang, B., Zheng, F., Römkens, M.J.M., Darboux, F. (2013). Soil erodibility for water erosion: A perspective and Chinese experiences. Geomorphology, 187: 1-10. https://doi.org/10.1016/j.geomorph.2013.01.018

[3] Giang, P.Q., Giang, L.T., Toshiki, K. (2017). Spatial and temporal responses of soil erosion to climate change impacts in a transnational watershed in Southeast Asia. Climate, 5(1): 22-29. https://doi.org/10.3390/cli5010022

[4] Priyono, K.D., Jumadi, Saputra, A., Fikriyah, V.N. (2020). Risk analysis of landslide impacts on settlements in Karanganyar, Central Java, Indonesia. International Journal of GEOMATE, 19(73): 100-107. https://doi.org/10.21660/2020.73.34128

[5] Maqsoom, A., Aslam, B., Hassan, U., Kazmi, Z.A., Sodangi, M., Tufail, R.F., Farooq, D. (2020). Geospatial assessment of soil erosion intensity and sediment yield using the Revised Universal Soil Loss Equation (RUSLE) model. ISPRS International Journal of GeoInformation, $9(6)$ : 356. https://doi.org/10.3390/ijgi9060356

[6] Gianinetto, M., Aiello, M., Vezzoli, R., Polinelli, F.N., Rulli, M.C., Chiarelli, D.D., Soncini, A. (2020). Future scenarios of soil erosion in the alps under climate change and land cover transformations simulated with automatic machine learning. Climate, 8(2): 28. https://doi.org/10.3390/cli8020028

[7] Keesstra, S.D., Bouma, J., Wallinga, J., Tittonell, P., Smith, P., Cerdà, A., Fresco, L.O. (2016). The significance of soils and soil science towards realization of the United Nations sustainable development goals. SOIL, 2(2): 111-128. https://doi.org/10.5194/soil-2-1112016

[8] Tundu, C., Tumbare, M.J., Onema, J.M.K. (2018). Sedimentation and its impacts/effects on river system and reservoir water quality: case study of Mazowe catchment, Zimbabwe. Proceedings of the International Association of Hydrological Sciences, 377: 57-66. https://doi.org/10.5194/piahs-377-57-2018

[9] Jiang, C., Zhang, H., Zhang, Z., Wang, D. (2019). Model-based assessment soil loss by wind and water erosion in China's Loess Plateau: Dynamic change, conservation effectiveness, and strategies for sustainable restoration. Global and Planetary Change, 172: 396-413. https://doi.org/10.1016/j.gloplacha.2018.11.002

[10] Bhandari, K.P., Darnsawasdi, R. (2015). Application of remote sensing and participatory soil erosion assessment approach for soil erosion mapping in a watershed. Walailak Journal of Science and Technology, 12(8): 689702. https://doi.org/10.14456/vol12iss8pp

[11] Naharuddin, Rukmi, Wulandari, R., Paloloang, A.K. (2018). Surface runoff and erosion from agroforestry land use types. JAPS: Journal of Animal \& Plant Sciences, 28(3): 875-882.

[12] Wahyuningrum, N., Putra, P.B. (2018). Land evaluation to assess performance of Rawakawuk Sub Watershed. Journal of Watershed Management Research, 2(1): 1-16.

[13] Alewell, C., Borrelli, P., Meusburger, K., Panagos, P. (2019). Using the USLE: Chances, challenges and limitations of soil erosion modelling. International Soil and Water Conservation Research, 7(3): 203-225. https://doi.org/10.1016/j.iswcr.2019.05.004

[14] Marques, V.S., Ceddia, M.B., Antunes, M.A.H., Carvalho, D.F., Anache, J.A.A., Rodrigues, D.B.B., Oliveira, P.T.S. (2019). USLE K-factor method selection for a tropical catchment. Sustainability (Switzerland), 11(7): 1840. https://doi.org/10.3390/su1107184

[15] Saiya, H.G., Dibyosaputro, S., Santosa, S.H.B. (2016). USLE estimation for potential erosion at Wae Heru Watershed and Wae Tonahitu Watershed, Ambon Island, Indonesia. Indonesian Journal of Geography, 48(2): 191. 
https://doi.org/10.22146/ijg.1761

[16] Taslim, R.K., Mandala, M., Indarto. (2019). The effect of landuse on erosion rate: a study at several watersheds in Tapal Kuda Region, East Java. Journal of Watershed Management Research, 3(2): 141-158.

[17] Zhang, K., Yu, Y., Dong, J., Yang, Q., Xu, X. (2019). Adapting \& testing use of USLE K factor for agricultural soils in China. Agriculture, Ecosystems and Environment. 269: 148-155. https://doi.org/10.1016/j.agee.2018.09.033

[18] Tsegaye, K., Addis, H.K., Hassen, E.E. (2020). Soil erosion impact assessment using USLE/GIS approaches to identify high erosion risk areas in the lowland agricultural watershed of blue nile basin, Ethiopia. International Annals of Science, 8(1): 120-129. https://doi.org/10.21467/ias.8.1.120-129

[19] Bagarello, V., Ferro, V., Pampalone, V. (2020). A comprehensive analysis of universal soil loss equationbased models at the Sparacia experimental area. Hydrological Processes, 34(7): 1545-1557. https://doi.org/10.1002/hyp.13681

[20] Da Silva, A.M., Alcarde, C., Hitomi, C. (2011). Natural potential for erosion for Brazilian Territory. In Soil Erosion Studies, 3-24. https://doi.org/10.5772/2316

[21] Panagos, P., Borrelli, P., Poesen, J., Ballabio, C., Lugato, E., Meusburger, K., Alewell, C. (2015). The new assessment of soil loss by water erosion in Europe. Environmental Science and Policy, 54: 438-447. https://doi.org/10.1016/j.envsci.2015.08.012

[22] Naharuddin, Wahid, A., Rukmi, Sustri. (2019). Erosion hazard assessment in forest and land rehabilitation for managing the tambun watershed in Sulawesi, Indonesia. Journal of Chinese Soil and Water Conservation, 50(3): 124-130. https://doi.org/10.29417/JCSWC.201909_50(3).0004

[23] Srinivasan, R., Singh, S.K., Nayak, D.C., Hegde, R., Ramesh, M. (2019). Estimation of soil loss by USLE model using remote sensing and GIS Techniques - A case study of Coastal Odisha, India. Eurasian Journal of Soil $\begin{array}{ll}\text { Science, } & 8(4):\end{array}$ https://doi.org/10.18393/ejss.598120

[24] Parmar, S. (2019). Sediment yield assessment using SAGA GIS and USLE model: A case study of watershed - 63 of Narmada River, Gujarat, India. International Journal of Engineering Trends and Technology, 67: 1-13. https://doi.org/10.14445/22315381/ijett-v67i8p201

[25] Bera, A. (2017). Estimation of soil loss by USLE model using GIS and remote sensing techniques: A case study of muhuri river basin, Tripura, India. Eurasian Journal of Soil Science, 206. https://doi.org/10.18393/ejss.288350

[26] Bagegnehu, B., Alemayehu, M., Nigatu, W. (2019). Geographic Information System (GIS) based soil loss estimation using Universal Soil Loss Equation Model (USLE) for soil conservation planning in Karesa Watershed, Dawuro Zone, South West Ethiopia. International Journal of Water Resources and Environmental Engineering, 11(8): 143-158. https://doi.org/10.5897/ijwree2018.0820..143-158

[27] Enyegue, T.T.O., Fokwa, D., Mbiakouo-Djomo, E.F., Njeugna, E. (2019). A simple device to evaluate the influence parameters of the water erosion of bare sandyclay soils of the city of Douala. Engineering, 11(12): 819-827. https://doi.org/10.4236/eng.2019.1112056
[28] Falcão, C.J.L.M., Duarte, S.M.A., da Silva Veloso, A. (2020). Estimating potential soil sheet Erosion in a Brazilian semiarid county using USLE, GIS, and remote sensing data. Environmental Monitoring and Assessment, 192(1): 47. https://doi.org/10.1007/s10661019-7955-5

[29] Petrikovičová, L., Rampašeková, Z., Sobocká, J. (2020). A detailed identification of erosionally endangered agricultural land in Slovakia (case study of Nitra Upland). Sustainability (Switzerland), 12(12): 4863. https://doi.org/10.3390/SU12124863

[30] Gebremedhin, Y.G. (2019). Soil erosion hazard in errer dembel sub-basin, in shinille zone of the Ethiopia Somali Regional State. International Journal of Environmental Sciences \& Natural Resources, 17(1): 01-09. https://doi.org/10.19080/ijesnr.2019.17.555951

[31] Agnihotri, D., Kumar, T., Jhariya, D. (2020). Intelligent vulnerability prediction of soil erosion hazard in semiarid and humid region. Environment, Development and Sustainability. https://doi.org/10.1007/s10668-02000685-2

[32] Nguyet, L.M., Minh, D.Q., Lan, P.T.H. (2019). Assessing the instability of Dong Nai River in Bien Hoa district using Bank Erosion Hazard Index (BEHI) and remote sensing and GIS. IOP Conference Series: Earth and Environmental Science, 272(2): 1-7. https://doi.org/10.1088/1755-1315/272/2/022219

[33] Arsyad, S. (2010). Soil and Water Conservation. IPB Press. Institute Pertanian Bogor. Bogor.

[34] Sadeghi, S.H., Zabihi, M., Vafakhah, M., Hazbavi, Z. (2017). Spatiotemporal mapping of rainfall erosivity index for different return periods in Iran. Natural Hazards, 87(1): 35-56. https://doi.org/10.1007/s11069017-2752-3

[35] Kiani-Harchegani, M., Sadeghi, S.H., Singh, V.P., Asadi, H., Abedi, M. (2019). Effect of rainfall intensity and slope on sediment particle size distribution during erosion using partial eta squared. Catena, 176: 65-72. https://doi.org/10.1016/j.catena.2019.01.006

[36] Taleshian Jeloudar, F., Ghajar Sepanlou, M., Emadi, S.M. (2018). Impact of land use change on soil erodibility. Global Journal of Environmental Science and Management, $\quad 4(1)$ : 59-70. https://doi.org/10.22034/gjesm.2018.04.01.006

[37] Kinnell, P.I.A. (2020). The influence of time and other factors on soil loss produced by rain-impacted flow under artificial rainfall. Journal of Hydrology, 587: 125004. https://doi.org/10.1016/j.jhydrol.2020.125004

[38] Ouyang, W., Hao, F., Skidmore, A.K., Toxopeus, A.G. (2010). Soil erosion and sediment yield and their relationships with vegetation cover in upper stream of the Yellow River. Science of the Total Environment, 409(2): 396-403. https://doi.org/10.1016/j.scitotenv.2010.10.020

[39] Dallahi, Y., Ouhammou, A., Sbai, M., Ei Aboudi, A., Boujraf, A. (2020). Assessment of the vegetation cover change impacts on water erosion, using Pap/Rac method in upstream of "ouljet soltane" dam, Central PleteauMorocco. Geographia Technica, 15(1): 153-161. https://doi.org/10.21163/GT_2020.151.14

[40] Ighile, E.H., Shirakawa, H. (2020). A Study on the effects of land use change on flooding risks in Nigeria. Geographia Technica, 15(1): 91-101. https://doi.org/10.21163/GT_2020.151.08 